\title{
Determination of freezing point standard for UHT milk'
}

\section{Determinação do parâmetro de crioscopia para leite UHT}

\author{
Vanerli Beloti ${ }^{*}$; Edson Antonio Rios ${ }^{2}$; Márcia Rocha Silva ${ }^{3}$; Ronaldo Tamanini; \\ Alberto Koji Yamada²; Livia Cavaletti Correa da Silva²
}

\begin{abstract}
The extended shelf life and undemanding storage requirements of UHT (ultra high temperature) milk make it the most consumed fluid milk in Brazil. The thermal treatment to which UHT milk is subjected alters casein micellar structure, leading to protein sedimentation and age gelation. Therefore, the current legislation allows the addition of up to $0.1 \%$ stabilizing salts (sodium citrate and/or sodium phosphates) in milk. The adding of stabilizing salts hinders the possibility of inclusion of freezing point and density as quality parameters of UHT milk. Evaluation of freezing point is the main test to detect adulteration of milk with water; however, addition of stabilizers alters its results. This study aimed to measure the alterations in freezing point and density caused by stabilizers in samples of pasteurized milk added with sodium citrate or sodium phosphates, in order to propose standards for freezing point and density for UHT milk. For this purpose, 16 aliquots of milk were prepared in nine repetitions with different concentrations $(0 \%, 0.001 \%, 0.01 \%, 0.05 \%, 0.075 \%, 0.1 \%, 0.125 \%$, and $0.15 \%)$ of sodium citrate or a commercial mix of sodium mono-, di- and triphosphate. The density and freezing point of all aliquots were tested. As expected, addition of stabilizers lowered the freezing point of milk. Addition of $0.1 \%$ citrate and commercial mix promoted an average reduction of $-0.021^{\circ} \mathrm{H}( \pm 0.001)$ and $-0.017^{\circ} \mathrm{H}$ $( \pm 0.002)$ in freezing point, respectively. However, no significant change in the density of milk was observed. Given that UHT milk industry usually adds the maximum limit of $0.1 \%$ of stabilizers in order to obtain proper effect, the interval from $-0.572^{\circ} \mathrm{H}$ to $-0.545^{\circ} \mathrm{H}$ can be suggested as the standard for freezing point to UHT milk. However, as the addition of stabilizers caused no significant change in the density of UHT milk, the density parameter of raw and pasteurized milk in the range from $1.028 \mathrm{~g} \cdot \mathrm{mL}^{-1}$ to $1.034 \mathrm{~g} \cdot \mathrm{mL}^{-1}$ could be applied to UHT milk.
\end{abstract}

Key words: Cryoscopy index, freezing point, milk, stabilizing agents, Quality, UHT

\section{Resumo}

Por apresentar prolongada vida útil e facilidade de estocagem, o leite Ultra Alta Temperatura (UAT) é o leite fluido mais consumido no Brasil. O processamento térmico ao qual o leite UHT é submetido provoca alterações na estrutura micelar da caseína favorecendo a precipitação proteica e a gelatinização; por isso, a legislação vigente autoriza a adição de estabilizantes (citrato e/ou fosfatos de sódio) na quantidade de até $0,1 \%$. A adição de estabilizantes ao leite UHT é a razão pela qual não se inclui o índice crioscópico e a densidade como parâmetros de qualidade para o leite UHT. A avaliação do índice crioscópico é a prova de eleição para detecção de fraudes por adição de água ao leite, no entanto a adição de estabilizantes interfere nos seus resultados. O presente estudo teve como objetivo aferir as alterações

\footnotetext{
${ }^{1}$ Prof $^{\mathrm{a}} \mathrm{Dr}^{\mathrm{a}}$, Dept ${ }^{\mathrm{o}}$ de Medicina Veterinária. Preventiva, Universidade Estadual de Londrina, UEL, Londrina, PR, Brasil. E-mail: vbeloti@uel.br

2 Discentes do Curso de Pós-Graduação em Ciência Animal, UEL, Londrina, PR, Brasil. E-mail: lipoa.uel@gmail.com; akyamada25@yahoo.com.br

3 Discente do Curso de Residência em Inspeção de Leite e Derivados, UEL, Londrina, PR, Brasil. E-mail: marcimrs@hotmail.com

4 Médico Veterinário, Dr., UEL, Londrina, PR, Brasil. E-mail: ronaldot@uel.br

* Author for correspondence
} 
promovidas por estabilizantes no ponto de congelamento e densidade em amostras de leite pasteurizado adicionado de citrato de sódio ou fosfatos de sódio, para sugerir padrões de crioscopia e densidade para o leite UHT. Para avaliar as alterações provocadas pela adição dos estabilizantes no leite, 16 alíquotas de leite foram preparadas em nove repetições, com diferentes concentrações $(0 \%, 0,001 \%, 0,01 \%$, $0,05 \%, 0,075 \%, 0,1 \%, 0,125 \%$ e $0,15 \%$ ) de citrato de sódio chamado de substância 1 e da substância 2: um mix comercial de mono, di e tri fosfato de sódio. As alíquotas foram submetidas à prova da densidade e crioscopia. Como esperado a adição de estabilizantes reduziu o ponto de congelamento do leite. A concentração de $0,1 \%$ de citrato e do mix comercial provocou uma redução média da crioscopia do leite de $-0,021^{\circ} \mathrm{H}( \pm 0,001) \mathrm{e}-0,017^{\circ} \mathrm{H}( \pm 0,002)$, respectivamente. Em relação à densidade, a adição dos estabilizantes não provocou alterações significativas. Considerando que as indústrias de leite UHT usualmente adicionam o limite máximo de $0,1 \%$ de estabilizantes para obterem o efeito desejado, podese sugerir como índice crioscópico para leite UHT o intervalo entre $-0,545$ a $-0,572^{\circ} \mathrm{H}$. Em relação à densidade, como não houve alteração significativa após a adição de estabilizantes, sugere-se que seja adotado o mesmo parâmetro estabelecido para os leites cru e pasteurizado, de 1,028 à 1,034 g/mL para o leite UHT.

Palavras-chave: Estabilizantes, índice crioscópico, leite, ponto de congelamento, qualidade, UHT

\section{Introduction}

UHT (ultra high temperature) milk is the most consumed fluid milk in Brazil. Due to its extended shelf life and undemanding storage, at room temperatures, UHT milk has excelled in the dairy market and has become a preferred choice among consumers (GOMES et al., 2012; MARTINS et al, 1999; VIANA; FERRAS, 2007). The market share of UHT in Brazilian fluid milk market has increased from 4\% in 1990 (EMBRAPA GADO DE LEITE, 2008) to $78 \%$ in 2011 (GUERRA, 2012). According to the Brazilian Association of Long Life Milk (ABLV), the national production of UHT milk surpassed 6.0 billion liters in 2012 (MILKPOINT, 2012).

The "Technical Regulation for Identity and Quality of UHT Milk", established by Brazil's Ministry of Agriculture, Livestock and Supply (MAPA), determines that UHT milk must be homogenized and subjected to heat treatment in a continuous flow thermal process at $130^{\circ} \mathrm{C}$ to $150^{\circ} \mathrm{C}$ for 2 to 4 seconds, followed by immediate cooling below $32^{\circ} \mathrm{C}$, and packed under aseptic conditions in sterile, hermetically sealed packages (BRASIL, 1997).

UHT milk has few and flexible standards for its quality control, as follows: it must be stable to ethanol or alizarol $68 \%(\mathrm{v} / \mathrm{v})$, present titratable acidity between 0.14 and $0.18 \mathrm{~g}$ lactic acid/100 mL of milk, have milk solids-not-fat (MSNF) contents of $8.2 \%, 8.3 \%$ or $8.4 \%$ for whole, semi-skimmed, or skimmed milk, respectively, and minimum 3\% fat content for whole milk, $0.6 \%$ to $2.9 \%$ for semiskimmed milk, and under $0.5 \%$ fat for skimmed milk. In addition, it has a single microbiological standard to maximum mesophilic aerobes of $100 \mathrm{CFU} / \mathrm{mL}$, which is assessed after package incubation at 35 $37^{\circ} \mathrm{C}$ for 7 days. Therefore, the quality control of UHT milk is vulnerable, and minor process flaws are difficult to detect in the absence of a freezing point and density standard, counts of indicator microorganisms such as coliforms, or research of pathogens as Salmonella, which are some of the standards required for the quality control of pasteurized milk.

The UHT thermal processing of milk, which is designed to eliminate both pathogenic and spoilage microorganisms from raw milk with minimal physicochemical and organoleptic alteration (RAYNAL-LJUTOVAC et al., 2007), affects casein micellar structure, inducing sedimentation and age gelation (CUNHA, 2001). Age gelation, which refers to a progressive increase in the viscosity of milk up to gel formation, and protein sedimentation during storage are the main factors that limit the shelf life of UHT milk (DATTA; DEETH, 2001; HILL, 1988). This process is aggravated during 
milk storage by heat-resistant proteases, frequently resulting in a product unfit for consumption.

In order to minimize the occurrence of sedimentation and age gelation, the UHT milk regulation (BRASIL, 1997) allows the addition of up to $0.1 \%$ protein stabilizers (sodium citrate and/or sodium phosphates) to increase the thermal stability of casein. This effect is mainly attributed to the stabilizers ability to sequester ionic calcium (SILVA, 2003), thus preventing the aggregation of casein micelles (DATTA; DEETH, 2001).

Since the addition of stabilizing salts to UHT milk can alter freezing point and relative density, these parameters are not applied to assess the quality of UHT milk. While the relative density of milk at $15^{\circ} \mathrm{C}$ is not a very accurate test, since it is influenced by all major components in milk, freezing point is the main test to assess fraudulent addition of water to milk, as it is directly proportional to the number of dissolved molecules in solution (FONSECA; SANTOS, 2000). The main substances in solution in milk are lactose and salts (HARDING, 1999). Thus, stabilizers added to UHT milk act as solutes and may directly influence freezing point and milk density. For raw and pasteurized milk, the standard freezing point ranges from $-0.550^{\circ} \mathrm{H}$ to $-0.530^{\circ} \mathrm{H}$ (BRASIL, 2011).

Furthermore, addition of water is not always deliberate, and may be a result of processing flaws such as the remaining of residual water in the heating equipment and the presence of micro-holes in heat exchangers, in either heating or cooling sectors. It will also occur whenever the heat system used is direct steam injection, which is the main system applied for UHT treatment and requires the removal of steam in a vacuum chamber. Therefore, the nonexistence of this standard in the quality control of UHT milk makes the final product vulnerable to these problems and to milk adulteration by water.
The aim of this study was to assess the alterations in freezing point and density of UHT milk after the addition of different concentrations of stabilizers such as sodium citrate and sodium phosphates to pasteurized milk, in order to suggest standards for freezing point and density for UHT milk.

\section{Materials and Methods}

To evaluate the changes caused by the addition of stabilizers such as sodium citrate and sodium phosphates to milk, 16 aliquots of homogenized pasteurized milk of the same brand collected from different batches were prepared. The first eight aliquots were added with different concentrations of sodium citrate, while the other eight were added with different concentrations of a commercial mix of mono-, di- and trisodium phosphate. The following concentrations of both stabilizers were tested: $0 \%$, $0.001 \%, 0.01 \%, 0,05 \%, 0.075 \%, 0.1 \%, 0.125 \%$, and $0.15 \%$. The concentration of $0 \%$ corresponded to negative control.

The density of the aliquots at $15^{\circ} \mathrm{C}$ and their freezing point (M90/BR-Laktron ${ }^{\circledR}$ ) were determined (BRASIL, 2006). Each of the eight concentrations for both stabilizers was tested in nine replicates, using pasteurized milk from different batches, totaling 144 measurements for density and 432 for freezing point, since freezing point measurements needed to be performed in triplicate. Data were analyzed using Microsoft Excel ${ }^{\circledR} 2010$ program.

\section{Results and Discussion}

The results of the analyses of pasteurized milk samples added with different concentrations of sodium citrate and the mixture of sodium phosphates stabilizers are presented in Table 1. As expected, the reduction in freezing point progressively amplified as the concentrations of the added stabilizers increased. 
Table 1. Mean alterations and standard deviation in the freezing point (degrees Horvet) of 432 freezing point measurements and 144 density $(\mathrm{g} / \mathrm{L})$ analyses before $(0 \%)$ and after addition of different concentrations of sodium citrate or a commercial mix of mono-, di-, and triphosphate stabilizers to pasteurized homogenized whole milk.

\begin{tabular}{|c|c|c|c|c|c|}
\hline \multirow{2}{*}{ Aliquot } & \multirow{2}{*}{$\begin{array}{c}\text { Concentration } \\
(\%)\end{array}$} & \multicolumn{2}{|c|}{ Sodium citrate } & \multicolumn{2}{|c|}{ Commercial mix of sodium phosphates } \\
\hline & & Crioscopia $\left({ }^{\circ} \mathrm{H}\right)$ & Densidade $\left(\mathrm{g} \mathrm{L}^{-1}\right)$ & Crioscopia $\left({ }^{\circ} \mathrm{H}\right)$ & Densidade $\left(\mathrm{g} \mathrm{L}^{-1}\right)$ \\
\hline 1 & 0.0 & $-0.535 \pm 0.020$ & $1.031,8 \pm 0.60$ & $-0.537 \pm 0.002$ & $1.031,6 \pm 0.32$ \\
\hline 2 & 0.001 & $-0.535 \pm 0.001$ & $1.031,4 \pm 0.52$ & $-0.537 \pm 0.000$ & $1.031,7 \pm 0.27$ \\
\hline 3 & 0.01 & $-0.537 \pm 0.001$ & $1.031,5 \pm 0.56$ & $-0.538 \pm 0.001$ & $1.031,6 \pm 0.56$ \\
\hline 4 & 0.05 & $-0.545 \pm 0.001$ & $1.031,7 \pm 0.70$ & $-0.545 \pm 0.001$ & $1.031,6 \pm 0.53$ \\
\hline 5 & 0.075 & $-0.551 \pm 0.001$ & $1.031,7 \pm 0.57$ & $-0.549 \pm 0.002$ & $1.031,9 \pm 0.57$ \\
\hline 6 & 0.1 & $-0.556 \pm 0.001$ & $1.032,1 \pm 0.54$ & $-0.554 \pm 0.002$ & $1.031,9 \pm 0.59$ \\
\hline 7 & 0.125 & $-0.560 \pm 0.001$ & $1.032,4 \pm 0.57$ & $-0.559 \pm 0.002$ & $1.032,3 \pm 0.44$ \\
\hline 8 & 0.15 & $-0.565 \pm 0.001$ & $1.032,2 \pm 0.55$ & $-0.565 \pm 0.002$ & $1.032,2 \pm 0.84$ \\
\hline
\end{tabular}

UHT milk regulation (BRASIL, 1997) allows the addition of a maximum of $0.1 \%$ stabilizers, and the dairy industry habitually uses the maximum permitted concentration, since lower concentrations may not provide sufficient stability to casein micelles. The concentration of $0.1 \%$ citrate and the commercial mix of stabilizers altered the freezing point of milk at $-0.021^{\circ} \mathrm{H}( \pm 0.001)$ and $-0.017^{\circ} \mathrm{H}( \pm 0.002)$, respectively. Figure 1 shows a linear progression of decreasing in freezing point proportional with the increase in the concentration of stabilizers added to milk.

Figure 1. Average reduction in freezing point (degrees Horvet) in 432 analyses of pasteurized homogenized whole milk after addition of different concentrations of sodium citrate or a commercial mix of mono-, di-, and triphosphate stabilizers.

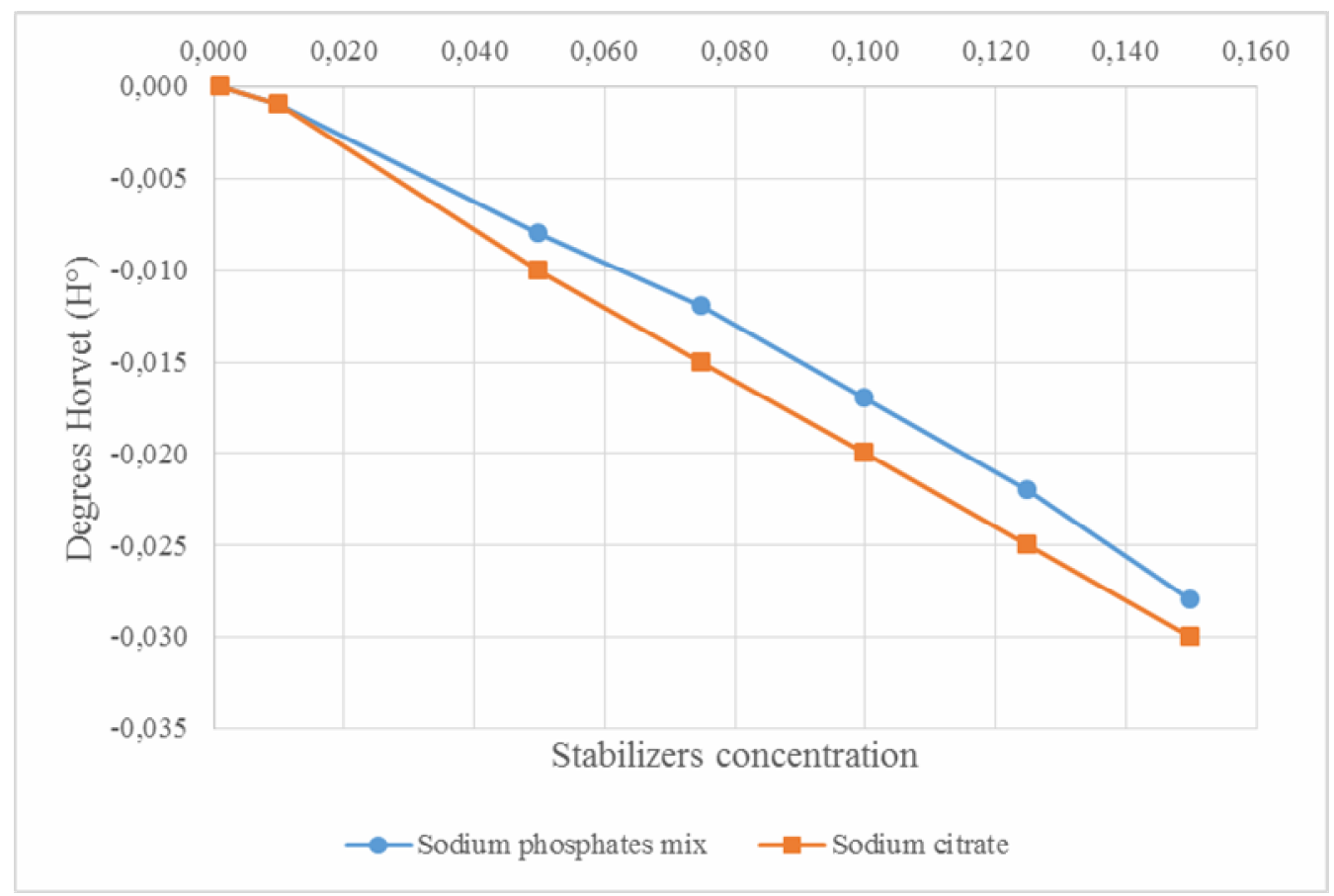


Considering the results of this research and that the legal freezing point interval of -0.550 to $-0.530^{\circ} \mathrm{H}$ established for raw and pasteurized milk with no added stabilizers, it can be proposed that UHT milk standard for freezing point should lie between -0.572 and $-0.545^{\circ} \mathrm{H}$. This range was obtained by adding the average reduction of $-0.015^{\circ} \mathrm{H}$ (equivalent to $-0.017^{\circ} \mathrm{H}$ with a standard deviation of $\pm 0.002^{\circ} \mathrm{H}$ ), promoted by the tested stabilizers in freezing point, to $-0.530^{\circ} \mathrm{H}$, which is the maximum freezing point permitted for raw milk. The same procedure was adopted to establish the lower limit, i.e. adding $-0.550^{\circ} \mathrm{H}$ to the maximum variation of $-0.021^{\circ} \mathrm{H}$, with a standard deviation of $\pm 0.001^{\circ} \mathrm{H}$. Thus, the proposed range includes the extreme possible results observed in this experiment; it is noteworthy that none of the samples presented results outside of this range.

The different concentrations of the two stabilizers showed no significant effects on the density of milk tested, and although minor variations were observed, the results were all within the range considered normal for raw and pasteurized milk. This is due to the fact that density is less specific and is subjected to more variables compared to freezing point, hence it is unable to detect the small variations in solute concentrations such as those used in this study. Even though density analysis, as demonstrated, is a less accurate test, it is still a helpful tool in detecting alterations. Consequently, it can be suggested that the standards established for raw and pasteurized milk of 1.028 to 1.034 g.mL $\mathrm{mL}^{-1}$ can be adopted for UHT milk.

Few studies that focus on the freezing point of milk during the phases of UHT processing have been conducted, probably due to the difficulty in accessing industrial processes. Martins et al. (2008) evaluated 60 samples of raw milk and 30 samples of UHT milk from the same industry, in 6 different processing stages. Comparing the averages of the freezing point before and after UHT milk processing reported by that study, it can be noted that the freezing point increased from $-0.535^{\circ} \mathrm{H}$ to $-0.527^{\circ} \mathrm{H}$. There was an average increase of $0.008^{\circ} \mathrm{H}$ in the freezing point after processing, from raw to UHT milk. This increase refers to the inclusion of about $1.5 \%$ of water originated from the direct steam injection process, without considering the alteration induced in the freezing point by the addition of stabilizers.

The inclusion of water occurs in UHT milk processing when direct steam injection system is used. This water must be removed in the subsequent step, using a vacuum chamber that should be adjusted for proper removal of incorporated water in the milk, otherwise residual water will remain in milk. Considering the maximum limit of $-0.545^{\circ} \mathrm{H}$, suggested by this study, the percentage of residual water on the data presented by Martins et al. (2008) would be even higher, approximately $4.5 \%$. A definite freezing point parameter for UHT milk would assist the industry in evaluating the proper removal of water after heat treatment of milk by direct steam injection.

The freezing point temperature is the most constant of milk characteristics; consequently, its determination is considered an accuracy test (TRONCO, 2008). Hence, the alteration of milk freezing point by addition of stabilizers demands a new approach in the regulatory aspect of UHT milk.

The determination of a standard freezing point for UHT milk is of greatest importance for fraud control and for proper restoration of the original water content in the product after direct steam injection. Furthermore, it should also be applied to control the amount of stabilizers added to milk, which along with freezing point, can also alter the $\mathrm{pH}$ of milk and reduce the amount of ionic calcium available (TSIOULPAS et al., 2010). Since a rapid and low-cost analysis to quantify the stabilizer salts added to UHT milk is not yet available, the establishment of a minimum limit on freezing point would be an important tool of quality control by regulatory agencies. 


\section{Conclusions}

The addition of stabilizers to UHT milk lowered its freezing point, as expected. Considering that a maximum of $0.1 \%$ stabilizers can be added to UHT milk to achieve the desired protein stability, and because of the corresponding alteration observed by this concentration, it can be suggested that the freezing point standard for UHT milk should observe the interval between $-0.545^{\circ} \mathrm{H}$ and $-0.572^{\circ} \mathrm{H}$.

Since the addition of stabilizers caused no significant changes in the density of UHT milk, the same density standard established for raw and pasteurized milk of 1.028 to 1.034 g. $\mathrm{mL}^{-1}$ can be adopted for UHT milk.

The determination of a standard for freezing point of UHT milk will allow detection of fraud by water addition, confirmation of the amount of water added directly to the milk during UHT heat treatment and its proper removal, as well as the excess use of stabilizers, when confronted with the product composition data.

\section{References}

BRASIL. Ministério da Agricultura, Pecuária e Abastecimento. Instrução Normativa 62, de 29 dez. 2011. Aprova o regulamento técnico de produção, identidade e qualidade do leite tipo a, o regulamento técnico de identidade e qualidade de leite cru refrigerado, o regulamento técnico de identidade e qualidade de leite pasteurizado e o regulamento técnico da coleta de leite cru refrigerado e seu transporte a granel. Diário Oficial [da] República Federativa do Brasil, Brasília, 30 dez. 2011. Seção 1, p. 6.

Ministério da Agricultura, Pecuária e Abastecimento. Instrução Normativa 68, 12 dez. 2006. Oficializa os métodos analíticos oficiais físicoquímicos, para controle de leite e produtos lácteos, em conformidade com o anexo desta Instrução Normativa, determinando que sejam utilizados nos Laboratórios Nacionais Agropecuários. Diário Oficial [da] República Federativa do Brasil, Brasília, 14 dez. 2006. Seção 1, p. 14-15.
Ministério da Agricultura, Pecuária e Abastecimento. Portaria n ${ }^{\circ} 370$, de 4 set. 1997. Aprova a inclusão do Citrato de sódio no regulamento técnico para fixação de identidade e qualidade do leite U.H.T (U.A.T). Diário Oficial [da] República Federativa do Brasil, Brasília, 8 set. 1997. Seção 1, p. 19700.

CUNHA, M. F. Revisão: leite UHT e o fenômeno de gelatinização. B. CEPPA, Curitiba, v. 19, n. 2, p. 341352, 2001.

DATTA, N.; DEETH, H. C. Age gelation of UHT milk a review. Food and Bioproducts Processing, London, v. 79, n. 4, p. 197-210, 2001.

EMPRESA BRASILEIRA DE PESQUISA AGROPECUÁRIA - EMBRAPA. Gado de leite. Comportamento das vendas internas de leite longa vida - 1990/2006. Brasília: EMBRAPA, 2008. Disponível em: <http://www.cnpgl.embrapa.br/>. Acesso em: 2 jul. 2010.

FONSECA, F. L.; SANTOS, M. V. Qualidade do leite e controle da mastite. São Paulo: Lemos Editorial, 2000. $175 \mathrm{p}$.

GOMES, L. M. C.; SILVEIRA, M. G.; OLIVEIRA, R. M. E.; MIAMOTO, J. B. M. Leite: influência da embalagem no comportamento do consumidor. Revista do Instituto de Laticínios Cândido Tostes, Juiz de Fora, v. 67, n. 384, p. 71-75, jan./fev. 2012.

GUERRA, J. O boom do leite UHT no Brasil. Bebedouro: Scot Consultoria, 2012. Disponível em: <http://www. scotconsultoria.com.br/noticias/artigos/24736/o$\% 3 \mathrm{Ci} \% 3$ Eboom\%3Ci\%3E-do-leite-uht-no-brasil.htm>. Acesso em: 27 set. 2013.

HARDING, F. Milk quality. Gaithersburg: Aspen Publication, 1999. $166 \mathrm{p}$.

HILL, A. Quality of ultra-high-temperature processed milk. Food Technology, Chicago, v. 12, n. 9, p. 92-97, 1988.

MARTINS, A. M. C. V.; ROSSI JUNIOR, O. D.; SALOTTI, B. M.; BURGER, K. P.; CORTEZ, A. L. L.; CARDOZO, M. V. Efeito do processamento UAT (Ultra Alta Temperatura) sobre as características físicoquímicas do leite. Ciência e Tecnologia de Alimentos, Campinas, v. 28, n. 2, p. 295-298, 2008.

MARTINS, R. S.; SANTOS, C. V.; TEIXEIRA, S. R. Alterações da rede logística e expansão do mercado de leite longa vida no Brasil. Revista de Administração da UFLA. Organizações Rurais e Agroindustriais, Lavras, v. 1, n. 2, p. 55-69, 1999. 
MILKPOINT. Crescem as vendas de leite longa vida e produção poderá ultrapassar 6 bilhões de litros em 2012. Piracicaba: MILKPOINT, 2012. Disponível em: $<$ http:// www.milkpoint.com.br/cadeia-do-leite/giro-lacteo/ crescem-as-vendas-de-leite-longa-vida-e-producaopodera-ultrapassar-6-bilhoes-de-litros-em-2012-79420n. aspx>. Acesso em: 28 out. 2013.

RAYNAL-LJUTOVAC, K.; PARK, Y. W; GAUCHERON, F.; BOUHALLAB, S. Heat stability and enzymatic modifications of goat and sheep milk. Small Ruminant Research, Amsterdam, v. 68, n. 1-2, p. 207220, 2007.

SILVA, P. H. F. Leite UHT: fatores determinantes para sedimentação e geleificação. 2003. Tese (Doutorado em Ciências dos Alimentos) - Universidade Federal de Lavras, Lavras.
TRONCO, V. M. Manual para inspeção da qualidade do leite. 3. ed. Santa Maria: Editora UFSM, 2008. 199 p.

TSIOULPAS, A.; KOLIANDRES, A.; GRANDISON, A. S.; LEWIS, M. J. Effects of stabiliser addition and in-container sterilisation on selected properties of milk related to casein micelle stability. Food Chemistry, London, v. 122, n. 4, p. 1027-1034, 2010.

VIANA, G.; FERRAS, R. P. R. Um estudo sobre a organização da cadeia produtiva do leite e sua importância para o desenvolvimento regional. Revista Capital Científico do Setor de Ciências Sociais Aplicadas, Guarapuava, v. 5, n. 1, p. 23-40, 2007. 
